\title{
Realizacja konstytucyjnej zasady nullum crimen sine lege certa w świetle art. 115 ust. 3 ustawy o prawie autorskim i prawach pokrewnych
}

JEL Classification: K11, K14, O34

Słowa kluczowe: prawo autorskie, karnoprawna ochrona własności intelektualnej, nullum crimen sine lege certa, konstytucyjność regulacji karnoprawnych

Keywords: copyright law, intellectual property protection by penal law, nullum crimen sine lege certa, the constitutionality of criminal law regulations

\begin{abstract}
Abstrakt: Celem artykułu jest analiza treści art. 115 ust. 3 pr.aut. oraz zbadanie konstytucyjności przepisu w oparciu o zasadę nullum crimen sine lege certa wyrażoną w art. 42 Konstytucji. Podstawą zarzutu niekonstytucyjności przepisu jest użycie w nim sformułowania: „Kto [...] w inny sposób narusza", będącego w opinii doktryny nieprecyzyjnym i sprzecznym z zasadą określoności prawa karnego. Na podstawie przytoczonych przepisów oraz praktyki ich stosowania autorka podejmuje próbę odpowiedzi na pytanie, czy regulacja zawarta w art. 115 ust. 3 pr.aut. jest zgodna z konstytucją, oraz polemizuje z kwestią dopuszczalności stosowania klauzul dopełniających w legislacji. W artykule przedstawiono argumenty za słusznością takiej regulacji oraz poglądy przeciwne, a także wnioski na tle wyroku z dnia 17 lutego 2015 roku, w którym Trybunał Konstytucyjny orzekł o zgodności przepisu z Konstytucją. Mimo aprobującego stanowiska TK kwestia konstytucyjności przepisu jest nadal kontrowersyjna i przysparza problemów w klasyfikacji czynów jako zabronionych na mocy ustawy o prawie autorskim. Niemniej jednak stosowanie klauzul dopełniających, w szczególności zawierających sformułowanie: „Kto [...] w inny sposób narusza", wydaje się nieuniknione ze względu na dynamiczny rozwój technologii oraz prawa. Zasadę określoności prawa karnego można urzeczywistnić, posługując się wykładnią prokonstytucyjną, mającą służyć maksymalnemu dostosowaniu norm prawnych do celów i wartości wyrażonych w Konstytucji. W artykule pośrednio opisano problematykę karnoprawnej ochrony praw własności intelektualnej z naciskiem na prawa autorskie.
\end{abstract}




\title{
Realization of a nullum crimen sine lege certa principle in light of Article 115 Paragraph 3 of a Polish Copyright Act
}

\begin{abstract}
The aim of the article is to analyze the content of Article 115 Paragraph 3 of the Polish Copyright Act and to examine the constitutionality of the provision based on the nullum crimen sine lege certa principle expressed in Article 42 of the Constitution. The basis for the allegation of the unconstitutionality of the provision is the Article's use of the phrase: "Who [...] otherwise violates", which is, in the opinion of the doctrine, imprecise and contrary to the principle of legal certainty in matters of criminal law. Basing on the quoted regulations and the practice the author tries to answer a question whether the content of Article 115 Paragraph 3 of the Polish Copyright Act is constitutional and subjects the issue of using such clauses to the polemics. The article presents arguments for the rightness of such regulation as well as opposing views and the final co nclusion based on the judgment of February 17, 2015, in which the Constitutional Tribunal adjudicated on the conformity of the regulation with the Constitution. Despite the approving position of the Constitutional Tribunal the issue of the constitutionality of the provision is still controversial and causes problems in the classification of acts as prohibited under the Copyright Act. Nevertheless, the use of complementary clauses in particular containing the phrase: "Who [...] otherwise violates" seems to be unavoidable due to the dynamic development of technology and law. The principle of legal certainty can be implemented using a pro-constitutional interpretation in order to maximize the alignment of legal norms with the objectives and values expressed in the Constitution. This paper will also examine the secondary issue of criminal law protection of intellectual property rights with an emphasis on copyright law.
\end{abstract}

\section{Uwagi wstępne}

Paremia łacińska „Nullum crimen sine lege”, oznaczająca, że nie jest przestępstwem czyn, który nie był zabroniony w momencie jego popełniania, wyraża jedną z najistotniejszych zasad prawa karnego. Jej źródeł można upatrywać w oświeceniowych koncepcjach, które w ustawie widziały gwarancję wolności jednostki przed arbitralnością władcy lub sędziego, a uznawanie danej kategorii zachowań za czyny zabronione pod groźbą kary należało do wyłącznej kompetencji ustawodawcy ${ }^{2}$. W polskim prawie zasada ta została uregulowana między innymi w art. 42 ust. 1 Konstytucji RP ${ }^{3}$, zgodnie z którym „odpowiedzialności karnej podlega ten tylko, kto dopuścił się czynu zabronionego pod groźbą kary przez ustawę obowiązującą w czasie jego popełnienia”. Podobny zapis został powtórzony w art. $1 \S 1$ Kodeksu karnego ${ }^{4}$ stanowiącym, że „odpowiedzialności karnej podlega ten tylko, kto popełnia czyn zabroniony pod groźbą kary przez ustawę obowiązującą w czasie jego popełnienia". Sformułowanie wskazanej zasa-

1 „Nie ma przestępstwa bez ustawy”.

2 A. Barczak-Oplustil, Obowiazywanie zasady nullum crimen sine lege. Wybrane problemy, „Czasopismo Prawa Karnego i Nauk Penalnych” 17, 2013, z. 3, s. 13.

3 Konstytucja Rzeczypospolitej Polskiej z dnia 2 kwietnia 1997 roku, Dz.U. z 1997 r. Nr 78 , poz. 483.

${ }^{4}$ Ustawa z dnia 6 czerwca 1997 roku — Kodeks karny, Dz.U. z 2017 r. poz. 2204; z 2018 r. poz. 20, 305, 663, dalej: k.k. 
dy w Konstytucji oraz na początku Kodeksu karnego wskazuje na jej doniosłość oraz nakreśla obowiązek kierowania się nią podczas wykładni i stosowania przepisów prawa karnego.

W doktrynie niekiedy doprecyzowuje się tę zasadę, między innymi poprzez wprowadzenie zakazu analogii i wykładni rozszerzającej na niekorzyść sprawcy (nullum crimen sine lege stricta), stwierdzenie, że nie ma przestępstwa bez ustawy spisanej (nullum crimen sine lege scripta) czy też nie ma przestępstwa bez ustawy ściśle określającej zakaz karny (nullum crimen sine lege certa). Punktem wyjścia do dalszych rozważań będzie postulat maksymalnej określoności czynu zabronionego.

Nie bez racji mówi się, że przepisy karne powinny opisywać przestępstwo w sposób maksymalnie dokładny. Wynika to chociażby z funkcji gwarancyjnej prawa karnego, pozwalającej określić, jakie czyny są zabronione pod groźbą kary, jakie będą konsekwencje działania sprzecznego z ustawą karną czy jak kształtuje się odpowiedzialność naruszającego przepisy. Obywatel ma prawo wiedzieć, jakie zachowanie jest uznawane za czyn niedozwolony oraz jakie grożą mu za nie sankcje. Ponadto warto zwrócić uwagę na silną korelację, jaka zachodzi między zasada nullum crimen sine lege certa a funkcją ogólnoprewencyjną. Prawo karne musi być bowiem zrozumiałe i klarowne, aby móc kształtować świadomość obywateli, budować w nich przekonanie, że warto przestrzegać prawa, którego celem jest ochrona społecznych wartości i dóbr. Jak wskazuje K. Dąbrowski: „prawo musi być jawne, komunikatywne a przede wszystkim pewne"5. Ów pewność należy pojmować jako przewidywalność dla adresata danej normy. Z punktu widzenia techniki legislacyjnej zasada określoności czynu zabronionego nakłada na ustawodawcę obowiązek stanowienia prawa w myśl poczynionych uwag, czego dowodem jest zawarte w $§ 75$ Rozporządzenia w sprawie „Zasad techniki prawodawczej”6 stwierdzenie, że „w przepisie karnym znamiona czynu zabronionego określa się w sposób wyczerpujący, bez odsyłania do nakazów albo zakazów zawartych w pozostałych przepisach tej samej ustawy lub w przepisach innych ustaw [...]”.

Reasumując, zasada określoności czynu zabronionego stanowi swojego rodzaju dyrektywę, którą ustawodawca powinien kierować się w procesie legislacyjnym, aby system prawny był spójny, a stosowana wykładnia jednolita. Niestety, dokonując analizy obowiązujących przepisów, można zauważyć, że postulat ten nie jest w pełni realizowany i zdarzają się sytuacje, w których dany typ czynu zabronionego nie jest w dostateczny sposób opisany i scharakteryzowany. Pojawiają się trudności w sprecyzowaniu znamion przestępstwa, niejasne lub zbyt ogólne pojęcia pozostawiające zbyt szerokie pole do interpretacji. Przykładem przepisu, odnośnie

5 K. Dąbrowski, Jednolitość wyktadni prawa karnego jako wymóg konstytucyjny, [w:] Prawo karne wobec Konstytucji, red. M. Pająk, R. Zawłocki, Warszawa 2018, s. 30.

${ }^{6}$ Rozporządzenie Prezesa Rady Ministrów z dnia 20 czerwca 2002 roku w sprawie „Zasad techniki prawodawczej”, Dz.U. z 2002 r. Nr 100, poz. 908. 
do którego pojawił się zarzut braku precyzyjnego określenia czynu zabronionego, jest art. 115 ust. 3 ustawy o prawie autorskim i prawach pokrewnych ${ }^{7}$. Przepis ten wzbudził w ostatnich latach wiele kontrowersji oraz wątpliwości interpretacyjnych ze względu na zawarte w nim sformułowanie: „Kto [...] w inny sposób [...] narusza". Trudno bowiem stwierdzić, jaką formę naruszenia miał na myśli ustawodawca, redagując przywołany przepis, oraz czy katalog czynów mieszczących się $w$ definicji nie jest zbyt szeroki. $Z$ uwagi na liczne dywagacje i narastające kontrowersje wokół tematu konstytucyjności przepisu w związku z zasadą nullum crimen sine lege certa Trybunał Konstytucyjny w 2015 roku pochylił się nad tym problemem.

\section{Stanowisko Trybunału Konstytucyjnego w sprawie zgodności art. 115 ust. 3 pr.aut. $z$ art. 42 ust. 1 Konstytucji}

Na wstępie należy zauważyć, że sprawa konstytucyjności art. 115 ust. 3 pr.aut. jest niezwykle interesująca, ponieważ w postępowaniu przed Trybunałem brały udział różne organy państwowe oraz Sejm. Inicjatorem był Rzecznik Praw Obywatelskich, który wniósł o zbadanie zgodności przywołanego przepisu z art. 42 Konstytucji. Udział w postępowaniu wzięli również Prokurator Generalny oraz Marszałek Sejmu. Ponadto Trybunał Konstytucyjny pośrednio starał się znaleźć odpowiedź na fundamentalne pytanie o słuszność i legalność stosowania w ustawodawstwie zwrotu „w inny sposób”, co, jak już wspomniano, przysparza wielu problemów interpretacyjnych. Sformułowanie to pojawia się bowiem nie tylko w ustawie o prawie autorskim i prawach pokrewnych, ale częstokroć występuje w innych aktach prawych, na przykład w Kodeksie karnym czy Kodeksie cywilnym ${ }^{8}$.

Dnia 17 lutego 2015 roku Trybunał Konstytucyjny wydał wyrok ${ }^{9}$, w którym orzekł o zgodności art. 115 ust. 3 pr.aut. z art. 42 Konstytucji. Przedmiotem niniejszego postępowania było zbadanie, czy przepis ten - czyli

Kto w celu osiągnięcia korzyści majątkowej w inny sposób niż określony w ust. 1 lub 2 narusza cudze prawa autorskie lub prawa pokrewne określone w art. 16, art. 17, art. 18, art. 19 ust. 1, art. 191, art. 86, art. 94 ust. 4 lub art. 97, albo nie wykonuje obowiązków określonych w art. 193 ust. 2 lub art. 20 ust. 1-4, podlega grzywnie, karze ograniczenia wolności albo pozbawienia wolności do roku

7 Ustawa z dnia 4 lutego 1994 roku o prawie autorskim i prawach pokrewnych, Dz.U. z 2017 r. poz. 880 , dalej: pr.aut.

${ }^{8}$ Zob. art. 217a Kodeksu karnego: „Kto uderza człowieka lub w inny sposób narusza jego nietykalność cielesną [...]”; art. $222 \S 2$ Kodeksu cywilnego: „Przeciwko osobie, która narusza własność w inny sposób aniżeli przez pozbawienie właściciela faktycznego władztwa nad rzeczą $[\ldots] "$.

9 Wyrok Trybunału Konstytucyjnego w sprawie o sygn. akt K 15/13, Warszawa, dnia 17 lutego 2015 roku, OTK-A 2015, nr 2, poz. 16. 
— czyni zadość konstytucyjnym wymogom określoności przepisów karnych i z punktu widzenia odpowiedzialności karnej może stanowić podstawę do takiej odpowiedzialności. Przepis ten zawiera regulację o charakterze klauzuli dopełniającej ${ }^{10}$ do dwóch poprzedzających ustępów, które w dostateczny sposób określają przesłanki odpowiedzialności karnej za naruszenie prawa do autorstwa w postaci oznaczania utworu własnym nazwiskiem lub pseudonimem, za zniekształcenie utworu czy wprowadzenie w błąd. Można by przypuszczać, że ustawodawca dążył w ten sposób do domknięcia katalogu czynów zabronionych pod groźbą odpowiedzialności karnej z tytułu naruszenia praw autorskich. Rezultat okazał się zgoła inny. W doktrynie podnosi się, że przepis ten cechuje się zbyt dużą niedookreślonością. Zgodnie z art. 42 ust. 1 Konstytucji: „Odpowiedzialności karnej podlega ten tylko, kto dopuścił się czynu zabronionego pod groźbą kary przez ustawę obowiązującą w czasie jego popełnienia". Jakie czyny są zatem zabronione na mocy przepisu art. 115 ust. 3 pr.aut.? Na to i na inne pytania starali się odpowiedzieć zarówno uczestnicy postępowania przed Trybunałem Konstytucyjnym, jak i sam Trybunat.

W dalszej kolejności omówione zostaną poszczególne zagadnienia, które były treścią wyroku o sygn. akt K 15/13.

\subsection{Problematyka karnoprawnej ochrony dóbr niematerialnych}

Przedmiotem ochrony prawa autorskiego są dobra niematerialne. W doktrynie przyjmuje się, że są to równocześnie autorskie dobra osobiste stanowiące szczególną kategorię dóbr osobistych powszechnego prawa cywilnego ${ }^{11}$, a prawa podmiotowe chroniące takie specyficzne wartości są szczególnymi cywilnymi prawami osobistymi ${ }^{12}$. Dobra niematerialne charakteryzuje to, że są wytworem ludzkiego umysłu i co do zasady istnieją niezależnie od nośnika, na którym są utrwalone (tzw. corpus mechanicum). Takimi dobrami w rozumieniu ustawy o prawie autorskim i prawach pokrewnych są te będące wynikiem twórczości artystycznej, naukowej, literackiej, określane jako przedmioty prawa autorskiego. To właśnie do nich nawiązuje przepis art. 115 ust. 3 pr.aut., przewidując sankcje karne za naruszenie przysługujących $\mathrm{z}$ nich praw.

Prawo autorskie to stosunkowo nowa dziedzina ${ }^{13}$, dlatego też nieustannie podejmowane są próby nowelizacji i dostosowywania przepisów do obecnych potrzeb. Ogólnie rzecz ujmując, cały system prawa własności intelektualnej jest materią niezwykle trudną do uregulowania ze względu na dynamikę zmian za-

10 J. Raglewski, Komentarz do art. 115 ustawy o prawie autorskim i prawach pokrewnych, [w:] Prawo autorskie i prawa pokrewne. Komentarz, red. nauk. D. Flisak, LEX 2015.

11 Ochrona na podstawie art. 23 i 24 k.c.

12 K. Czub, Prawa osobiste twórców dóbr niematerialnych. Zagadnienia konstrukcyjne, LEX 2011.

13 Fundamenty współcześnie znanego nam prawa autorskiego wykształciły się w XIX wieku. 
chodzących w świecie nowych technologii, Internetu i digitalizacji. Jak słusznie powiedziała w wywiadzie dla Gazety Prawnej Elżbieta Traple: „Postępu technologicznego nigdy nie uda się nam dogonić. Zawsze będzie on o krok przed regulacjami prawnymi"14. Ustawodawca, biorąc pod uwagę powyższe okoliczności, zdecydował się uregulować kwestię odpowiedzialności karnej za naruszenie praw autorskich za pomocą klauzuli dopełniającej, obejmując tym samym „każdy inny sposób naruszenia" niż wskazany w ust. 1 i 2 art. 115 pr.aut. Tym samym rozwój techniki w obszarze praw autorskich nie skutkuje koniecznością każdorazowej nowelizacji ustawy, lecz jedynie powinnością zastosowania właściwej wykładni. Alternatywą klauzuli dopełniającej mogłaby być regulacja kazuistyczna, to znaczy enumeratywne wymienienie przypadków, sytuacji, w których dochodziłoby do naruszenia praw autorskich określonych w przepisie 115 pr.aut. Koncepcja ta została poddana krytyce Marszałka Sejmu, który w postępowaniu przed Trybunałem zauważył, że

zasady określoności regulacji z zakresu prawa represyjnego nie można rozumieć [...] jako wymogu tworzenia kazuistycznych regulacji karnoprawnych. [...] trzeba mieć na względzie, że przepisy ustawy o prawie autorskim i prawach pokrewnych stosowane są w warunkach niezwykle dynamicznego rozwoju techniki w obszarze tych praw, wprowadzania do obrotu i upowszechniania się nowych środków rejestracji i odtwarzania informacji, dźwięku i obrazu, co w oczywisty sposób wyklucza przyjmowanie kazuistycznych regulacji.

Dobra objęte prawem autorskim są chronione od momentu ich powstania, bez konieczności dokonywania ich rejestracji ${ }^{15}$, dlatego liczba nowych przypadków form naruszenia stale rośnie. Podkreśla to J. Błeszyński, wskazując, że: „wraz z poszerzeniem skali eksploatacji twórczości chronionej prawem autorskim wrasta skala naruszeń praw autorskich"16. Dlatego też stanowisko Marszałka wydaje się słuszne, a regulacja kazuistyczna niewłaściwa dla tej dziedziny prawa.

\subsection{Znamiona typu czynu zabronionego $w$ art. 115 ust. 3 pr.aut.}

Całość rozważań na temat konstytucyjności art. 115 ust. 3 pr.aut. w nawiązaniu do zasady nullum crimen sine lege certa zasadniczo sprowadza się do rekonstrukcji znamion czynu zabronionego. W prawie karnym fundamentalną kwestią jest stwierdzenie, czy dane zachowanie jest sprzeczne z prawem, a więc czy sposób postępowania sprawcy wyczerpuje znamiona typu czynu zabronionego. Ponadto, aby czyn mógł rodzić odpowiedzialność karną, muszą być spełnione dodatkowe przesłanki, takie jak możliwość przypisania winy oraz większa niż znikoma

${ }^{14}$ Zob. http://muzykaiprawo.pl/prawo-autorskie-trzeba-napisac-od-nowa/ (dostęp: 10.05.2018).

15 A. Wojciechowska, Cywilnoprawna ochrona własności intelektualnej w Polsce, cejsh.icm. edu.pl/cejsh/element/bwmeta1.element.desklight-7b099f91-f2cd-4db4-af4c-766a052df473/c/Kwartalnik1_2013_7.pdf (dostęp: 5.05.2018).

16 J. Błeszyński, Kopiowanie utworów chronionych prawem autorskim za pomoca urządzeń reprograficznych, [w:] Prace z prawa prywatnego. Księga Pamiatkowa ku czci sędziego Janusza Pietrzykowskiego, red. Z. Banaszczyk, Warszawa 2000, s. 27. 
szkodliwość społeczna ${ }^{17}$. Brak spełnienia którejkolwiek z nich skutkuje niemożliwością uznania zachowania za przestępnego, gdyż wymienione cechy stanowią elementy konstytutywne przestępstwa.

Pojęcie znamienia czynu zabronionego może być różnie rozumiane. W ujęciu dogmatycznym przyjmuje się, że jest to cecha składająca się na ogólnie i abstrakcyjnie określane przestępstwo ${ }^{18}$. Definiowanie znamion poprzez wskazanie, że są to cechy przestępstwa, wymaga nakreślenia, czym są owe cechy. Tradycyjnie uznaje się, że są to wyrażenia językowe stanowiące komunikat będący wypowiedzią ustawodawcy, skierowany do adresatów normy prawnej ${ }^{19}$. Nie należy utożsamiać znamion czynu z pojedynczymi wyrazami, gdyż zgodnie z zasadami logiki prawniczej mogą one być nazwami prostymi lub złożonymi. Ponadto interpretując znaczenie danego zwrotu, należy pamiętać, że ze względu na specyfikę języka prawnego posługiwanie się jedynie słownikowymi definicjami słów lub ich powszechnie przyjętym znaczeniem może okazać się niewystarczające. Konieczne jest sięgnięcie do definicji legalnych, zasad techniki legislacji czy orzecznictwa. Ta sama uwaga tyczy się norm prawnych, których rekonstrukcja polega na kompleksowej analizie przepisów prawa karnego, z uwzględnieniem dyrektyw interpretacyjnych, kontekstu związanego z resztą przepisu, a nawet zasad wynikających z Konstytucji, takich jak nullum crimen sine lege certa. Norma prawna nie jest jedynie zbiorem słów, które należy analizować każde z osobna. Jak zauważył S. Żółtek: „Można zaryzykować twierdzenie, że znamiona otrzyma się po zdekodowaniu normy”. Ustalenie ich znaczenia będzie zatem wymagało nie tylko literalnego odczytania przepisu, lecz zastosowania wykładni zespołu znamion składających się na typ czynu zabronionego. Dlatego też w prawie karnym często używane jest pojęcie dekodowania ${ }^{20}$.

W świetle poczynionych uwag należy pochylić się nad treścią art. 115 ust. 3 pr.aut. Zgodnie z przepisem odpowiedzialności karnej podlega ten, kto w sposób inny niż opisany w poprzedzających ustępach narusza cudze prawa autorskie lub prawa pokrewne opisane $\mathrm{w}$ enumeratywnie wymienionych artykułach oraz, co ważne, robi to w celu osiągnięcia korzyści majątkowej. Jest to przykład pozakodeksowej regulacji prawnokarnej. Formalnie źródłem prawa karnego jest Kodeks karny, natomiast ustawodawca dopuszcza możliwość unormowania tej materii również w ustawach szczególnych, takich jak właśnie ustawa o prawie autorskim i prawach pokrewnych. Największą trudność w stosowaniu art. 115 ust. 3 pr.aut. stanowi określenie znamion, jakie muszą być wyczerpane, by móc pociągnąć ko-

17 Wynika to z art. 1 k.k.

18 S. Żółtek, Znaczenie normatywne ustawowych znamion typu czynu zabronionego, Warszawa 2017 , s. 50-51.

19 Ibidem, s. 53.

20 J. Wyrembak, Zasadnicza wykładnia znamion przestępstw: pozycja metody językowej oraz rezultatów jej użycia, Warszawa 2009, s. 298. 
goś do odpowiedzialności karnej. Innymi słowy pojawia się pytanie, jakie zachowanie jest zabronione?

Trybunał Konstytucyjny w swoich orzeczeniach wielokrotnie powoływał się na przepis art. 42 Konstytucji, dokonując wykładni bądź analizy konstytucyjności przepisów prawa karnego. Tym samym wzorcem posłużył się w wyroku o sygn. akt K15/13, orzekając o zgodności art. 115 ust. 3 pr.aut. z Konstytucją. Zanim jednak zapadł ten wyrok, tą samą kwestią zajął się Sąd Rejonowy dla Warszawy-Żoliborza w Warszawie i, co ciekawe, zajął stanowisko odmienne niż TK. W jego ocenie bowiem przepis ten nie jest zgodny z Konstytucją, co wynika z faktu, że „nie spełnia wymogu określoności, ponieważ nie wynika precyzyjnie z niego, jakie zachowania są przez ten przepis penalizowane". Następnie sąd zwrócił uwagę, że konstrukcja tego przepisu jest przez doktrynę prawa uznawana za wadliwą, gdyż zwrot „w inny sposób niż określony [...] narusza” pozbawiony jest znamion czynu zabronionego, co z kolei uniemożliwia rozpoznanie, jakie zachowania będą podlegać karze ${ }^{21}$. Trybunał Konstytucyjny co prawda umorzył postępowanie w tej sprawie (ze względu na niedopuszczalność wydania wyroku), ale w uzasadnieniu ustosunkował się do postawionego mu pytania, stwierdzając, że użycie zwrotu „W inny sposób narusza” jest precyzyjne oraz że

przepis ten nie jest, wbrew przytaczanemu przez sąd stanowisku doktryny [...] pozbawiony zespołu znamion czynu zabronionego i pozwala rozpoznać, jakie zachowania będą podlegać karze, ponieważ znamiona te można zrekonstruować w toku wykładni jako naruszenie cudzych praw autorskich lub praw pokrewnych w celu osiągnięcia korzyści majątkowej. Dla zaistnienia przestępstwa nie jest istotne, w jaki sposób następuje naruszenie praw autorskich lub praw pokrewnych. Ważne jest, że doszło do naruszenia tych praw i miało to miejsce w celu osiągnięcia korzyści majątkowej ${ }^{22}$.

Trybunał Konstytucyjny konsekwentnie podtrzymał to stanowisko w wyroku o sygn. akt K15/13. Przywołując podobne argumenty, orzekł o zgodności art. 115 ust. 3 pr.aut. $z$ art. 42 ust. 1 Konstytucji.

Mimo że Trybunał przesądził o konstytucyjności wspomnianego przepisu, w doktrynie ${ }^{23}$ nadal pojawiają się wątpliwości co do słuszności i precyzji regulacji. W wyroku poruszono wiele wątków, co stanowi powód uczynienia tej problematyki przedmiotem pogłębionej analizy.

W pierwszej kolejności należy przeanalizować kwestię posłużenia się przez ustawodawcę nieprecyzyjną klauzulą „w inny sposób”. Problem ten wysunął się już na pierwszy plan w związku z oceną Rzecznika Praw Obywatelskich, który uznał, że kwestionowany przepis wprowadza otwarty zakres znamion czynu za-

21 Postanowienie z dnia 28 maja 2007 roku, Sąd Rejonowy dla Warszawy-Żoliborza w Warszawie, Wydział IV Karny.

22 Postanowienie Trybunału Konstytucyjnego z dnia 21 października 2009 roku, P 31/07.

23 R. Markiewicz, S. Sołtysiński, Konstytucyjne aspekty praw autorskich (uwagi na marginesie dwóch orzeczeń Trybunału Konstytucyjnego), „Państwo i Prawo” 2015, nr 12. 
bronionego, co nie pozwala ustalić, jakie zachowania będą podlegały karze. Jak wspomniano, sformułowanie to wskazuje na zastosowanie konstrukcji prawnej klauzuli dopełniającej. Wnioskodawca, podobnie jak prokurator, wyraził swoje obawy odnośnie do ryzyka wkroczenia sądu w sferę tworzenia prawa, co jest zastrzeżone dla ustawodawcy. Należy zgodzić się, że taki sposób regulacji może prowadzić do dowolności orzekania i co za tym idzie - stanowienia, a nie stosowania prawa przez sądy. Byłoby to z pewnością naruszenie zasady trójpodziału władzy oraz ingerowanie w kompetencje innych organów. Sądy są uprawnione do udzielania odpowiedzi na pytania prawne, dokonywania wykładni przepisów, ale nie powinny wkraczać w sferę tworzenia prawa. Dlatego też pogląd prokuratora $\mathrm{w}$ tej kwestii zasługuje na aprobatę. $\mathrm{Z}$ drugiej strony posługiwanie się zwrotem „W inny sposób” jest powszechnie przyjętą przez ustawodawcę techniką legislacji głównie w sytuacjach, gdy trudno sprecyzować, jakie są możliwe zachowania jednostki ${ }^{24}$. Trybunał Konstytucyjny uzasadnia to koniecznością ,zachowania ogólności prawa, w tym również prawa karnego" ${ }^{25}$. Co z tym idzie — „sądom należy pozostawić możliwość wykładni prawa w procesie jego stosowania"26. Przykładowo w art. $217 \S 1$ k.k. mowa jest o ,uderzeniu człowieka lub w inny sposób naruszeniu jego nietykalność cielesnej”. W myśl przyjętych interpretacji oznacza to, że strona przedmiotowa czynu polega na tym, że sprawca narusza nietykalność cielesną drugiej osoby ${ }^{27}$. Analogicznie można by uznać, że w kontekście art. 115 ust. 3 pr.aut. powinno się penalizować każde zachowanie naruszające prawa autorskie lub pokrewne, a nawet, idąc dalej, uznać rozbicie regulacji na trzy ustępy za zbędne, ponieważ wystarczyłoby unormowanie o treści „Kto narusza cudze prawa autorskie lub prawa pokrewne...". Oczywiście dokonując takiego uproszczenia, pomijamy przesłankę celu osiągnięcia korzyści majątkowej.

Nie ma wątpliwości, że aby móc mówić o odpowiedzialności karnej z art. 115 ust. 3 pr.aut., musi dojść do wspomnianego „naruszenia prawa”. Przesłanka ta stanowi znamię strony przedmiotowej czynu zabronionego i charakteryzuje sposób działania lub zaniechania sprawcy. Naruszenie prawa jest, najogólniej rzecz ujmując, postępowaniem sprzecznym z przepisami prawa materialnego lub procedury. Przepis ten nie precyzuje, o jakie formy naruszenia chodzi, a tych zasadniczo może być nieograniczona ilość. Trudno bowiem wyliczyć możliwe zachowania sprawcy będące czynami przestępnymi na mocy wspomnianego artykułu. Jak słusznie stwierdził prokurator, poważną przeszkodę interpretacyjną stanowi brak legalnej definicji naruszenia praw autorskich. Ustawodawca co prawda ogranicza

24 Zob. art. 217 § 1 k.k.; art. 17 ust. 1c ustawy z dnia 17 grudnia 2004 roku o odpowiedzialności za naruszenie dyscypliny finansów publicznych, Dz.U. z 2017 r. poz. 1311.

25 Zob. wyrok z 28 czerwca 2005 roku, sygn. SK 56/04, OTK ZU nr 6/A/ 2005, poz. 67.

26 Ibidem.

27 Tak J. Piórkowska-Flieger, Komentarz do art. 217 Kodeksu karnego, [w:] Kodeks karny. Komentarz, LexisNexis 2006. 
zakres stosowania tego przepisu do konkretnie wskazanych osobistych i majątkowych praw autorskich, ale problem zbyt dużej ogólności pojęcia „narusza” pozostaje aktualny. Część doktryny stoi na stanowisku, że jest to przepis blankietowy ${ }^{28}$ oraz że ,tak szeroko ujęta podstawa odpowiedzialności karnej pokrywa się zatem częściowo z innymi typami czynów zabronionych"29. Czym jest bowiem owo naruszenie? Definicje słownikowe są niewystarczające, gdyż zgodnie z nimi przez naruszenie rozumie się , uszkodzenie, zepsucie, zakłócenie, złamanie umowy, przepisów, prawa lub niedotrzymanie słowa" ${ }^{30}$. Wracamy więc do ogólnego pojęcia naruszenia prawa. Konsekwentnie wykładnia sądowa wydaje się nieunikniona. Co więcej, ze względu na dynamikę zmian zachodzących w prawie autorskim samo powoływanie się na definicje z orzecznictwa jest niewystarczające. Mogą bowiem pojawić się nowe formy owego naruszenia, nieuwzględnione wcześniej przez sądy i doktrynę. Może to prowadzić do kuriozalnej sytuacji, gdy potencjalny sprawca czynu zabronionego $\mathrm{z}$ art. 115 ust. 3 pr.aut. będzie zmuszony czekać na wyrok sądu w swojej sprawie celem ustalenia, czy złamał prawo, czy też nie. Pomijając, że jest to bardzo niekomfortowe dla adresata tego typu norm prawnokarnych, należy podkreślić, że przeczy to zasadzie określoności prawa karnego i nie spełnia funkcji gwarancyjnej. Trybunał Konstytucyjny w wyroku wypowiada się w tym temacie, stwierdzając, że owszem, Konstytucja dopuszcza stosowanie norm prawa karnego o charakterze blankietowym, ale tak, by odkodowanie treści regulacji nie budziło wątpliwości ani dla adresata, ani dla organów stosujących prawo ${ }^{31}$. Jednocześnie orzekając o zgodności przepisu art. 115 ust. 3 pr aut., uznaje, że adresat tej normy jest w stanie rozpoznać, czy jego zachowanie in concreto wypełnia znamiona czynu zabronionego, jakim jest naruszenie praw autorskich.

$\mathrm{Z}$ ochrony przewidzianej w art. 115 ust. 3 pr.aut. może korzystać każda osoba, której prawa autorskie lub pokrewne zostały naruszone w celu osiągnięcia korzyści majątkowej. W literaturze wskazuje się, że ze względu na działanie celowe możemy mówić jedynie o przestępstwie popełnionym umyślnie, z zamiarem bezpośrednim, kierunkowym, obejmującym cel i sposób działania sprawcy ${ }^{32}$. Osiągnięcie korzyści majątkowej należy pojmować jako powiększenie majątku, co nie jest równoznaczne z otrzymaniem pieniędzy. Może przybrać formę umowy darowizny, zwolnienia z długu lub dowolnej transakcji zwiększającej aktywa

28 „I. Andrejew stwierdza, że znamiona niepozwalające odróżnić zachowania przestępnego od legalnego, a więc nie pozwalają na jednoznaczne zidentyfikowanie karnoprawnego zakazu są „pustą abstrakcją”, zob. idem, Ustawowe znamiona czynu: typizacja i kwalifikacja przestępstw, Warszawa 1978, s. 69.

29 J. Raglewski, op. cit.

30 Naruszenie, [hasło w:] Słownik języka polskiego PWN, https://sjp.pwn.pl/szukaj/NARUSZENIE.html (dostęp: 19.09.2018).

31 Wyrok Trybunału Konstytucyjnego w sprawie o sygn. akt K 15/13...

32 Por. wyrok Sądu Apelacyjnego w Krakowie z dnia 17 września 2015 roku, II AKa 188/15. 
majątkowe bądź zmniejszającej pasywa ${ }^{33}$. Znamię podmiotowe działania w celu osiągnięcia korzyści majątkowej jest dostatecznie precyzyjne i nie wymaga dalszej analizy.

\section{Ratio legis ochrony karnoprawnej autorskich dóbr niematerialnych}

O prawie karnym mówi się, że jest ono instrumentem wtórnym względem porządku aksjologicznego oraz ultima ratio, a zatem stosuje się je, gdy inne metody zawodzą. Reakcja prawnokarna powinna więc dotyczyć sytuacji, w których mimo moralnych i etycznych przesłanek, mimo zasad postępowania przyjętych przez dane społeczeństwo jednostka narusza przepisy, a alternatywne mechanizmy ochrony praw zawodzą. Na gruncie ustawy o prawie autorskim i prawach pokrewnych pojawia się zatem pytanie o zasadność wprowadzenia w rozdziale XIV rzeczonej ustawy przepisów o charakterze karnym. Prawo autorskie należy do dziedziny prawa własności intelektualnej, a więc bliższe jest prawu cywilnemu niż karnemu. Jak zostało wspomniane na wstępie, przedmiotem ochrony prawa autorskiego są dobra niematerialne. Mogą być one chronione w dwojaki sposób - albo przez prawo karne, albo szeroko pojęte prawo cywilne (prawo autorskie, własności przemysłowej lub jako dobra osobiste, co zostało opisane powyżej). Warto zauważyć, że dualizm ten wynika z odmiennych celów, jakie przyświecają poszczególnym rodzajom ochrony. Jak trafnie stwierdził R. Golat: „Ochrona karnoprawna ma na celu przeciwdziałać tym bezprawnym zachowaniom, którym przypisać można odpowiednio wysoki stopień społecznej szkodliwości"34. Chroniony jest więc nie tylko interes podmiotów uprawnionych $\mathrm{z}$ tytułu praw autorskich, lecz także porządek publiczny. Z punktu widzenia polityki kryminalnej prawo karne jako ultima ratio powinno być stosowane akcydentalnie, a w pierwszej kolejności należałoby zwrócić się ku sankcjom cywilnym. Część doktryny podaje w wątpliwość zasadność sankcji karnych w prawie autorskim, ponieważ mowa jest o stosunkach cywilnoprawnych ${ }^{35}$. W Kodeksie cywilnym przewidziane są takie instrumenty, jak odszkodowanie, naprawienie wyrządzonej szkody, wezwanie do zaprzestania naruszeń dóbr osobistych czy inne instrumenty mające chronić interesy jednostki, której prawa są naruszane.

Zarówno sankcje karne, jak i cywilne uległy w ostatnich latach zaostrzeniu. Jest to spowodowane chęcią zwiększenia ochrony twórców, których w dobie Internetu coraz częściej dotyczy zjawisko piractwa czy plagiatu. Nie ulega wątpliwości, że cel poszerzania zakresu penalizacji jest słuszny, niemniej powinno się tego do-

33 J. Raglewski, op. cit.

34 R. Golat, Karnoprawna ochrona dóbr niematerialnych, [w:] idem, Dobra niematerialne. Kompendium prawne, Warszawa 2005, s. 180-181.

35 Z. Ćwiąkalski, [w:] J. Barta et al., Prawo autorskie i prawa pokrewne. Komentarz, Warszawa 2011, s. 737. Podobnie RPO w wyroku o sygn. akt K15/13. 
konywać ostrożnie, aby nie doprowadzić do sytuacji nadmiernej ingerencji w wolność jednostki. Prawo karne powinno być dolegliwe proporcjonalnie do stopnia naruszenia prawa. W doktrynie podnosi się, że regulacja zawarta w art. 115 ust. 3 pr.aut. stanowi zbyt szeroką penalizację wkraczania w prawa autorskie i wpływa hamująco na tworzenie i rozpowszechnianie utworów ${ }^{36}$. Autorzy w obawie przed ryzykiem naruszenia praw autorskich mogą ograniczać swoją twórczość, a nawet jej zaprzestać. Odbiorcy natomiast nie będą korzystali z instytucji dozwolonego użytku, co znacznie zahamuje rozwój sztuki i nauki. Reasumując, zbyt intensywna ochrona praw wyłącznych uniemożliwia optymalną eksploatację dóbr ${ }^{37}$ oraz może mieć negatywne skutki dla twórców. Dozwolony użytek będący formą ograniczenia autorskich praw majątkowych może być dla nich jednocześnie szansą na rozwój. Dla wielu twórców fakt zdobycia popularności jest kluczowy dla dalszej działalności. Dozwolony użytek stwarza możliwość dzielenia się z przyjaciółmi i bliskimi zakupionymi filmami, książkami itp. W ten sposób dzieło ma szansę stać się znanym utworem, co kolejno przekłada się na zyski ze sprzedaży. Należy więc stwierdzić, że kluczowe jest znalezienie równowagi między interesem twórców a interesem publicznym, tak, by żadna strona nie była poszkodowana przy jednoczesnym nastawieniu na rozwój sztuki i nauki. Konsekwentnie regulacje prawnokarne w odniesieniu do własności intelektualnej są potrzebne, gdyż sankcje cywilne nie zawsze okazują się wystarczające i skuteczne.

\section{Wnioski}

Realizacja konstytucyjnej zasady nullum crimen sine lege certa nie jest prostą sprawą, szczególnie w perspektywie dynamicznie rozwijających się dziedzin, takich jak prawo autorskie. Ustawodawca, regulując odpowiedzialność karną za naruszenie praw autorskich, posłużył się sformułowaniem: „w inny sposób narusza", które w opinii doktryny nie jest precyzyjne i w konsekwencji powinno zostać uznane za niekonstytucyjne w świetle art. 42 Konstytucji. Stąd też kwestia ta została poddana pod rozwagę Trybunału Konstytucyjnego, który w wyroku K15/13 stwierdził, że art. 115 ust. 3 pr.aut. spełnia wymóg określoności prawa karnego, adresat normy ma możliwość oceny, czy jego zachowanie in concreto narusza prawa autorskie, a sądy, dokonując wykładni, będą doprecyzowywać treść regulacji.

Zasadniczym problemem kodyfikacji prawa jest to, że ciężko abstrakcyjnie opisać wszystkie możliwe formy naruszenia. Dlatego też posługiwanie się klauzulami dopełniającymi jest nieuniknione. Kazuistyczne wyliczenie przypadków jest niewystarczające i może jedynie stanowić punkt wyjścia, wskazywać, co ustawodawca miał na myśli, jaki miał cel, tworząc daną regulację. Pomocne okazuje się zastosowanie wykładni prokonstytucyjnej, która co do zasady skutkuje

\footnotetext{
36 R. Markiewicz, S. Sołtysiński, op. cit., s. 8.

37 Ibidem, s. 5.
} 
modyfikacją treści i/lub zakresu wyinterpretowanej normy z uwagi na wzorce konstytucyjne, co ma służyć maksymalnemu dostosowaniu norm prawnych do celów i wartości wyrażonych w Konstytucji.

Prawo karne jak żadna inna dyscyplina prawnicza jest powiązana z wartościowaniami moralnymi oraz emocjami społecznymi, dlatego w pierwszej kolejności powinno spełniać funkcję prewencyjną i chronić interesy twórców, a dopiero później nakładać kary na naruszających prawo. W ten sposób przy odpowiedniej wykładni nawet nieprecyzyjny przepis nie będzie krzywdzący dla adresata normy prawnokarnej. Należy jednak unikać nadmiernej interpretacji prowadzącej do zatarcia granicy między stosowaniem a stanowieniem prawa. Ponadto regulacja zawarta w art. 115 ust. 3 pr.aut. nie powoduje zbyt szerokiego zakresu penalizacji. Konieczne jest bowiem spełnienie przesłanki działania w celu osiągnięcia korzyści majątkowej. Jeżeli ktoś działa z zamiarem bezpośrednim, to nie może być nieświadomy swoich czynów. Na mocy art. 115 ust. 3 pr.aut. nie ma więc ryzyka pociągnięcia do odpowiedzialności karnej osoby, która nieświadomie narusza prawa autorskie. Nie będzie bowiem wyczerpane znamię podmiotowe czynu zabronionego. Na podstawie poczynionych uwag należy uznać, że zaskarżony przepis jest konstytucyjny i przy zastosowaniu właściwej wykładni dostatecznie chroni zarówno interesy twórców, jak i interes publiczny.

\section{Bibliografia}

Barczak-Oplustil A., Obowiazywanie zasady nullum crimen sine lege. Wybrane problemy, „Czasopismo Prawa Karnego i Nauk Penalnych” 17, 2013, z. 3, Kraków 2013.

Błeszyński J., Kopiowanie utworów chronionych prawem autorskim za pomoca urządzeń reprograficznych, [w:] Prace z prawa prywatnego. Księga Pamiątkowa ku czci sędziego Janusza Pietrzykowskiego, red. Z. Banaszczyk, Warszawa 2000.

Czub K., Prawa osobiste twórców dóbr niematerialnych. Zagadnienia konstrukcyjne, LEX 2011.

Ćwiąkalski Z., [w:] J. Barta, M. Czajkowska-Dąbrowska, Z. Ćwiąkalski, R. Markiewicz, E. Traple, Prawo autorskie i prawa pokrewne. Komentarz, Warszawa 2011.

Dąbrowski K., Jednolitość wyktadni prawa karnego jako wymóg konstytucyjny, [w:] Prawo karne wobec Konstytucji, red. M. Pająk, R. Zawłocki, Warszawa 2018.

Golat R., Karnoprawna ochrona dóbr niematerialnych, [w:] idem, Dobra niematerialne. Kompendium prawne, Warszawa 2005.

Markiewicz R., Barta J., Prawo autorskie, Warszawa 2016.

Markiewicz R., Sołtysiński S., Konstytucyjne aspekty praw autorskich (uwagi na marginesie dwóch orzeczeń Trybunatu Konstytucyjnego), „Państwo i Prawo” 2015, nr 12.

Piórkowska-Flieger J., Komentarz do art. 217 Kodeksu karnego, [w:] Kodeks karny. Komentarz, LexisNexis 2006.

Prawo autorskie. System Prawa Prywatnego, t. 13, red. J. Barta, Warszawa 2017.

Raglewski J., Komentarz do art. 115 ustawy o prawie autorskim i prawach pokrewnych, [w:] Prawo autorskie i prawa pokrewne. Komentarz, red. nauk. D. Flisak, LEX 2015.

Wyrembak J., Zasadnicza wyktadnia znamion przestępstw: pozycja metody językowej oraz rezultatów jej użycia, Warszawa 2009.

Żółtek S., Znaczenie normatywne ustawowych znamion typu czynu zabronionego, Warszawa 2017. 


\section{Akty prawne}

Konstytucja Rzeczypospolitej Polskiej z dnia 2 kwietnia 1997 roku, Dz.U. z 1997 r. Nr 78, poz. 483. Ustawa z dnia 6 czerwca 1997 roku — Kodeks karny, Dz.U. z 2017 r. poz. 2204; z 2018 r. poz. 20, 305,663 .

Rozporządzenie Prezesa Rady Ministrów z dnia 20 czerwca 2002 roku w sprawie „Zasad techniki prawodawczej”, Dz.U. z 2002 r. Nr 100, poz. 908.

Ustawa z dnia 4 lutego 1994 roku o prawie autorskim i prawach pokrewnych, Dz.U. z 2017 r. poz. 880.

\section{Orzecznictwo}

Postanowienie Trybunału Konstytucyjnego z dnia 21 października 2009 roku, P 31/07.

Postanowienie z 28 maja 2007 roku, Sąd Rejonowy dla Warszawy-Żoliborza w Warszawie, Wydział IV Karny.

Wyrok Sądu Apelacyjnego w Krakowie z dnia 17 września 2015 roku, II AKa 188/15.

Wyrok Trybunału Konstytucyjnego w sprawie o sygn. akt K 15/13, Warszawa, dnia 17 lutego 2015 roku, OTK-A 2015, nr 2, poz. 16.

Wyrok z 28 czerwca 2005 roku, sygn. SK 56/04, OTK ZU nr 6/A/ 2005, poz. 67

\section{Strony internetowe}

http://muzykaiprawo.pl/prawo-autorskie-trzeba-napisac-od-nowa/.

Naruszenie, [hasło w:] https://sjp.pwn.pl/szukaj/NARUSZENIE.html.

Wojciechowska A., Cywilnoprawna ochrona własności intelektualnej w Polsce cejsh.icm.edu.pl/ cejsh/element/bwmeta1.element.desklight-7b099f91-f2cd-4db4-af4c-766a052df473/c/Kwartalnik1_2013_7.pdf.

\section{Realization of a nullum crimen sine lege certa principle in light of Article 115 Paragraph 3 of a Polish Copyright Act}

\section{Summary}

The implementation of the constitutional principle nullum crimen sine lege certa is not simple, especially in the perspective of dynamically developing areas such as copyright law. To regulate criminal liability for copyright infringement, the legislator used the phrase "otherwise violates", which in the opinion of the doctrine is not precise and consequently should be recognized as unconstitutional in light of Article 42 of the Polish Constitution. For this reason the issue was taken into consideration by the Constitutional Tribunal. The Tribunal, in its judgment K15/13, stated that Article 115 Paragraph 3 of the Polish Copyright Act meets the requirement of the well-defined criminal law. The addressee of the regulation has the opportunity to assess whether his/her behavior in concreto infringes copyright. The courts will clarify the content of the regulation by interpreting it.

The fundamental problem of codification of the law is that it is difficult to describe in abstracto all of the possible forms of violation. Therefore, in my opinion, the use of complementary clauses is inevitable. Casuistic enumeration is insufficient and can only indicate what the legislator meant and the intentions and purpose of creating a given regulation. The use of pro-constitutional interpretation has proven helpful, which in principle results in a modification of the content and/or scope of the interpreted norm due to constitutional models, which is intended to maximize legal norms for purposes and values expressed in the Constitution. Criminal law, like no other legal discipline, is associated with moral valuation and social emotions, which is why it should include a prerequi- 
site preventive function and protect the interests of creators and then impose penalties on those who violate the law. In this way, with proper interpretation, even an imprecise provision will not harm the addressee of the criminal law. However, excessive interpretation should be avoided due to risk of blurring the boundary between the application and creation of law. In addition, I believe the regulation contained in Article 115 Paragraph 3 of the Polish Copyright Act does not allow for a wide range of potential penalizations. According to the legislation it is necessary to act in order to obtain material benefits, and therefore, if someone acts with direct intention, they cannot be unaware of his/her actions. Therefore, basing on Article 115 Paragraph 3 of the Polish Copyright Act, there is no risk of prosecution of a person who unknowingly infringes copyright; the subjective feature of a prohibited act will not be fulfilled. In the light of these observations, it appears that the appealed provision is constitutional and with the appropriate interpretation sufficiently protects both the interests of the creators and the public interest. 